\title{
Pelatihan Strategi Koping Fokus Emosi untuk Menurunkan Stres Akademik pada Mahasiswa
}

\section{Emotional Focus Coping Strategy Training for Decreasing Academic Stress on Students}

\author{
F. Octaffia Mahardhani ${ }^{1}$, Anggitya Nur Ramadhani ${ }^{1}$, Rizky Melyn Isnanti ${ }^{2}$, Tri Nur \\ Chasanah $^{2}$, Ardian Praptomojati ${ }^{1}$ \\ ${ }^{1}$ Fakultas Psikologi, Universitas Gadjah Mada \\ ${ }^{2}$ Fakultas Ilmu Sosial dan Ilmu Politik, Universitas Gadjah Mada
}

Submitted 5 April $2020 \quad$ Accepted 20 May $2020 \quad$ Published 22 May 2020

\begin{abstract}
Academic stress is a problem that often occurs in college students. The various adjustments faced by students in their new roles and environment often become their stressors, especially for them who do not have adaptive coping skills. This study aimed to investigate the effect of emotion-focus coping strategy training programs to decrease levels of academic stress on college students. The study's design was a quasi-experimental method with one group pretest-posttest design. Subjects in the study were 16 students $(\mathrm{M}=19.81$ years; $\mathrm{SD}=0.911)$ from one of the colleges in Yogyakarta, Indonesia. The instruments used were Emotion-Focus Coping Scale and Academic Stress Scale. A statistical analysis of the paired sample t-test showed that the training of emotion-focus coping strategies was proven to decrease academic stress on college students with $t(15)=2.149 ; p=0.048(p<0.05)$. The results of this study are expected to be used as an intervention reference for mental health programs in the college.
\end{abstract}

Keywords: academic stress; college student; emotion-focused coping strategy training

Abstrak. Stres akademik menjadi permasalahan yang banyak terjadi pada mahasiswa. Berbagai penyesuaian yang harus dihadapinya dalam peran dan lingkungan barunya tersebut kerapkali menjadi stressor tersendiri, terlebih bagi mahasiswa yang tidak memiliki kemampuan koping yang adaptif. Penelitian ini bertujuan untuk melihat pengaruh program pelatihan strategi koping fokus emosi untuk menurunkan tingkat stres akademik pada mahasiswa. Desain studi menggunakan metode eksperimen quasi dengan one group pretest-posttest design. Subjek dalam penelitian berjumlah 16 mahasiswa $(M=19,81$ tahun; $S D=0,911)$ dari salah satu perguruan tinggi di Yogyakarta, Indonesia. Instrumen pengukuran yang digunakan meliputi Skala Koping Fokus Emosi dan Skala Stres Akademik. Analisis statistik paired sample t-test menunjukkan bahwa pelatihan strategi koping fokus emosi terbukti dapat menurunkan stres akademik pada mahasiswa dengan $t(15)=2,149 ; p=0,048(p<0,05)$. Hasil penelitian ini diharapkan dapat dijadikan sebagai referensi intervensi bagi program kesehatan mental di perguruan tinggi.

Kata kunci: mahasiswa; pelatihan strategi koping fokus emosi; stres akademik 
Perubahan peran menjadi mahasiswa tentunya memberikan kebanggaan tersendiri bagi para remaja. Tidak hanya berubahnya status, melainkan semakin terbukanya lingkungan sosial yang lebih luas bagi para remaja. Di satu sisi, berbagai tantangan dan penyesuaian menjadi hal yang akan dihadapi oleh para remaja ketika memasuki dunia mahasiswa. Beberapa ahli menjelaskan bahwa fase transisi dari SMA ke perkuliahan merupakan fase penyesuaian yang berat, seperti penyesuaian tinggal jauh terpisah dari rumah bagi mahasiswa yang merantau (Thurber \& Walton, 2012), penyesuaian sosial (Aderi, Jdaitawi, Ishak, \& Jdaitawi, 2013), penyesuaian finansial (Tran, Lam, \& Legg, 2018), serta penyesuaian akademis (Beiter et al., 2015).

Berbagai penyesuaian tersebut dapat menjadi stressor tersendiri bagi para mahasiswa, terlebih bagi mereka yang mengalami kesulitan dalam beradaptasi (Ababu, Yigzaw, Besene, \& Alemu, 2018). Tak sedikit dari mereka yang merasakan distress dan tidak bisa mengatasinya sehingga berpengaruh terhadap kesehatan mentalnya (Bamuhair et al., 2015). Studi menunjukkan bahwa prevalensi stres dan gangguan mental akibatnya seperti kecemasan dan depresi di kalangan pelajar semakin meningkat dari tahun ke tahun di berbagai negara (Auerbach et al., 2018; Eisenberg, Gollust, Golberstein, \& Hefner, 2007). Gangguan mental yang tidak segera diatasi tersebut dapat berkembang menjadi permasalahan yang lebih serius di masa dewasa (Copeland \& Shanahan, 2009).

Aktivitas akademik menjadi bagian integral dari kehidupan para mahasiswa. Tanpa penyesuaian yang adaptif, mahasiswa dapat mengalami stres akademik yang selanjutnya dapat mengarah pada berbagai permasalahan mental lainnya. Studi menunjukkan bahwa tekanan akademis untuk memenuhi persyaratan nilai, ujian, tugas-tugas, hingga tuntutan untuk dapat melakukan manajemen waktu yang baik menjadi sumber stres akademik yang besar bagi para mahasiswa (Kumaraswamy, 2013; Misra \& McKean, 2000). Berbagai tekanan akademis tersebut dapat mengarahkan pada stres tekanan akademik, yang akan berimbas pada berbagai permasalahan lainnya lebih jauh seperti penurunan performansi akademik, tingkat drop out yang tinggi, menurunnya kualitas hidup, risiko gangguan kesehatan fisik dan mental, hingga rendahnya kesejahteraan (Khan, Altaf, \& Kausar, 2013; Pascoe, Hetrick, \& Parker, 2020; Yovita \& Asih, 2017).

Lazarus dan Folkman mendefinisikan stres sebagai situasi di mana tuntutan terhadap seseorang melebihi kapasitas atau sumber daya yang dimiliki oleh individu. Nevid, Rathus, dan Greene (2014) menambahkan bahwa stres dapat ditunjukkan dengan adanya tekanan fisik dan psikis oleh tuntutan dalam diri dan juga lingkungan sekitar. Dengan adanya tuntutan tersebut, individu membutuhkan adanya respons yang adaptif (Atwater, 1983). Secara garis besar, stres sendiri tidak hanya bergantung pada kondisi eksternal, melainkan juga pada kerentanan individual dan kecukupan sistem pertahanannya. Individu memiliki cara bereaksi yang beragam terhadap stresssor yang mungkin sejenis (Lazarus, 1976).

Stres akademik merupakan produk dari kombinasi tuntutan akademik yang 
melebihi kemampuan adaptif individu. Ketika seseorang tidak dapat mengatasinya secara efektif, maka akan memiliki dampak terhadap kesehatan psiko-sosial-emosional (Wilks, 2008). Stres akademik juga memiliki kaitan dengan tingkat penyesuaian diri mahasiswa. Ketika individu menunjukkan tingkat stres akademik yang tinggi, maka akan berdampak pula pada kemampuan penyesuaian dirinya (Hussain, Kumar, \& Husain, 2008).

Stres akademik jika merunut kembali pada definisi stres yang diungkapkan oleh Lazarus dan Folkman (1984), dapat diartikan sebagai reaksi yang dirasakan oleh mahasiswa karena adanya persepsi terhadap tuntutan akademik terhadap dirinya yang melebihi kapasitas atau sumber daya yang dimilikinya. Taylor (1995) menambahkan bahwa ketika mengalami stres, individu akan menunjukkan respons fisiologis (seperti detak jantung meningkat, berkeringat, gangguan pernafasan), respons kognitif (seperti sulit berkonsentrasi, mudah lupa, tidak mampu membuat keputusan), respons emosi (seperti takut, marah, tertekan), dan respons perilaku (sulit tidur, terganggunya nafsu makan, penurunan prestasi).

Dalam dunia akademik, stres akademik dapat terjadi karena beberapa stressor yang signifikan dipersepsi oleh mahasiswa. Shirom (1986) dalam studinya menemukan bahwa ada empat hal utama yang menjadi sumber stres akademik mahasiswa. Domain pertama adalah hal-hal yang berkaitan dengan ujian, seperti kekhawatiran tidak mampu mengerjakan soal ujian, adanya banyak ujian dalam periode waktu tertentu, ataupun waktu yang terbatas untuk mempersiapkan ujian. Domain kedua, adanya tugas-tugas dalam kelas sehingga mengharuskannya untuk membaca banyak materi, mengerjakan makalah/paper, ataupun berhadapan dengan banyaknya deadline tugas-tugas. Domain yang ketiga berkaitan dengan aktivitas pembelajaran di kelas seperti tuntutan untuk membaca materi setiap kali sebelum kelas dimulai, keharusan untuk menghadapi pertanyaan-pertanyaan yang kerap kali secara langsung diberikan di kelas, serta keharusan untuk selalu terlibat aktif dalam sesi diskusi kelas. Domain yang keempat adalah tantangan dalam menyeimbangkan urusan kampus dengan keluarga di rumah, seperti adanya kewajiban di rumah yang harus dikerjakan namun kadang kala bersamaan dengan kegiatan kampus, datang ke perkuliahan setelah lelah mengerjakan tugas rumah, hingga kemampuan untuk bisa menyeimbangkan waktu bagi mereka yang harus bekerja part-time di sela-sela perkuliahan.

Berbicara mengenai stres akademik, penting untuk meninjau kembali mengenai mekanisme koping yang dimiliki oleh mahasiswa. Koping dipandang sebagai proses penting dalam proses pengelolaan stres. Lazarus dan Folkman (1984) mendefinisikan strategi koping sebagai segala usaha yang dilakukan individu untuk mengubah sisi kognitif dan perilakunya dalam mengelola tuntutan eksternal dan internal yang spesifik, yang melebihi sumber daya dari individu tersebut. Secara umum, terdapat tiga jenis strategi koping yang berbeda, yaitu problemfocused coping yaitu berfokus dengan segala upaya untuk melawan dan mengatasi 
kondisi yang menekan, emotion-focused coping yaitu berfokus pada upaya untuk mengatur respons-respons emosional yang muncul dari kondisi yang menekan, dan seeking social support yang dikarakteristikkan dengan pencarian dukungan dan bantuan emosional dari orang lain.

Studi mengenai koping terus berkembang dalam berbagai penelitian. Beberapa ahli lain mengategorikan koping ke dalam tiga bentuk yang berbeda antara lain task-oriented coping, emotion-oriented coping, dan avoidance-oriented coping. Berbagai usaha yang dilakukan menggunakan pendekatan pemecahan masalah dengan berusaha secara aktif mencari alternatif solusi dari kondisi yang menimbulkan stres dikategorikan sebagai task-oriented coping. Lain halnya dengan emotion-oriented coping yang dicirikan dengan usaha untuk melakukan regulasi emosi terhadap kondisi yang menjadi stressor melalui aktivitas-aktivitas sadar pengelolaan emosi. Jenis yang terakhir, yaitu avoidance-oriented coping, dicirikan dengan melakukan berbagai kegiatan yang disengaja untuk melepaskan atau menghindarkan diri dari situasi yang penuh tekanan (Endler \& Parker, 1990, 1994).

Kemampuan mahasiswa dalam melakukan koping menjadi perhatian para peneliti. Koping yang adaptif menjadi kunci untuk dapat mengurangi stres, meningkatkan toleransi terhadap stres, serta mencegah terjadinya penurunan prestasi akademik (Gustems-Carnicer, Calderón, \& Calderón-Garrido, 2019). Lebih jauh, koping yang adaptif berkorelasi dengan tingkat depresi pada mahasiswa (Chou, Chao, Yang, Yeh, \& Lee, 2011; Sapranaviciute, Padaiga, \& Pauzienè, 2013).
Ironisnya, tidak semua mahasiswa memiliki kemampuan koping yang adaptif terhadap stres akademik. Studi yang dilakukan Bamuhair dan koleganya (2015) menemukan bahwa dari survei yang dilakukan terhadap 378 mahasiswa di Arab Saudi, sebanyak 53\% mengalami tingkat stres akademik yang tinggi dimana sepertiganya tidak memiliki kemampuan koping yang adaptif. Beberapa bentuk koping yang ditemukan justru menyalahkan diri sendiri (self-blaming) dan mengkritik diri sendiri (self-critical) secara berlebihan. Al-Dubai, Al-Naggar, Alshagga, dan Rampal (2011) dalam studinya juga menemukan bahwa dari 376 mahasiswa, sebanyak $46 \%$ merasakan stres. Beberapa di antaranya masih belum memiliki bentuk koping yang adaptif, seperti penyangkalan, menyalahkan diri sendiri, penyalahgunaan zat, dan minum alkohol. Di Korea Selatan, bentuk koping maladaptif yang ditemukan pada mahasiswa antara lain menggunakan game dan internet secara berlebihan, serta melakukan perilaku yang menyimpang secara sosial seperti minum alkohol, vandalisme, perilaku kekerasan pada orang lain, dan bullying (Park \& Kim, 2018).

Studi terhadap 184 mahasiswa di salah satu universitas di Indonesia menunjukkan bahwa sebanyak $74,46 \%$ mahasiswa di antaranya mengalami tingkat stres sedang dan sebanyak 17,93\% mengalami tingkat stres tinggi (Maulana, Soleha, Saftarina, \& Siagian, 2014). Studi lain juga dilakukan oleh Aini (2017) terhadap 110 mahasiswa keperawatan di Indonesia dan ketika dikategorikan ke dalam dua kategori, sebanyak 51\% masuk pada kategori sedang dan sebanyak $49 \%$ masuk pada kategori stres yang tinggi. 
Domain stres tertinggi yang muncul ternyata berasal dari faktor akademis. Kondisi stres tersebut jika tidak diikuti dengan strategi koping yang adaptif akan menjadi faktor risiko bagi munculnya berbagai permasalahan kesehatan mental dan permasalahan akademik.

Berdasarkan fakta-fakta tersebut, penelitian ini bertujuan untuk mengembangkan program manajemen stres melalui pelatihan strategi koping yang adaptif. Program ini merupakan adaptasi dari program yang telah dikembangkan sebelumnya dalam penelitian Rembulan (2009). Program berfokus pada pelatihan strategi koping yang berfokus pada emosi. Beberapa referensi telah menunjukkan bahwa strategi koping fokus emosi mampu mengurangi tingkat stres dan berhubungan dengan kesehatan fisik yang lebih positif (Passer \& Smith, 2007; Stanton et al., 2000). Hal ini menjadi sumber yang sangat penting bagi mahasiswa sebagaimana seorang remaja yang dalam tahapannya sedang mengalami kondisi emosi yang cenderung belum matang dan mengalami dinamika yang kerap kali disebut "storm and stress"(Santrock, 2016). Koping fokus emosi yang adaptif akan mampu memberikan ruang baginya untuk mengidentifikasi emosi yang ia rasakan setiap kali menghadapi kondisi-kondisi yang menekan, serta dapat memproses dan mengekspresikan emosi secara adaptif (Lazarus \& Folkman, 1984). Kondisi ini diharapkan dapat menjadi benteng dari terjadinya stres akademik bagi mahasiswa. Hal inilah yang mendasari pengembangan studi ini. Hipotesis yang diajukan dalam penelitian ini adalah pelatihan strategi koping fokus emosi dapat menurunkan stres akademik pada mahasiswa. Hasil dari penelitian ini diharapkan dapat menjadi referensi program manajemen stres yang dapat diberikan kepada mahasiswa sebagai upaya mengatasi stres akademik.

\section{Metode}

\section{Partisipan}

Penelitian ini menggunakan teknik purposive sampling. Kriteria inklusi partisipan dalam penelitian antara lain: (1) berstatus sebagai mahasiswa; (2) memiliki skor koping fokus emosi yang tergolong rendah atau sedang berdasarkan pengukuran skala koping fokus emosi; (3) memiliki skor stres akademik yang tergolong tinggi atau sedang berdasarkan skala stres akademik; (4) tidak didiagnosis mengalami gangguan psikotik atau gangguan psikologis berat lainnya; (5) tidak sedang menjalani tritmen psikologis atau farmakoterapi, dan (6) dengan kesediaannya mau berpartisipasi dalam penelitian. Peneliti melakukan skrining kepada sejumlah mahasiswa dan didapatkanlah 16 partisipan yang memenuhi kriteria inklusif.

\section{Instrumen penelitian}

Penelitian ini menggunakan dua buah skala sebagai instrumen pengambil data. Skala yang pertama adalah Skala Koping Fokus Emosi yang telah dikembangkan sebelumnya pada penelitian Rembulan (2009). Skala ini terdiri dari 20 aitem dan berusaha untuk mengukur aspek-aspek keterampilan dalam strategi koping fokus emosi antara lain kemampuan mengenal emosi, mengekspresikan emosi, mengelola emosi, dan mengubah emosi negatif 
menjadi emosi positif. Salah satu aitem pertanyaannya adalah "Ketika saya sedih, saya cenderung diam dan menyimpan kesedihan tersebut". Bentuk dari skala ini adalah skala likert 4 poin $(1=$ sangat tidak sesuai, $2=$ tidak sesuai, $3=$ sesuai, dan $4=$ sangat sesuai) dengan koefisien reliabilitas $\alpha=$ 0,905 .

Skala yang kedua adalah Skala Stres Akademik yang telah dikembangkan pada penelitian Nugraheni (2012). Skala ini terdiri dari 30 aitem dan mengukur aspek dari stres akademik melalui empat manifestasi simtom stres yang berbeda, yaitu respons fisik, afektif, kognitif, dan perilaku. Aitem pertanyaannya terdiri dari identifikasi simtom yang dirasakan, sebagai contoh adalah "Takut ketinggalan materi dibandingkan teman-teman" yang kemudian diminta untuk diberikan respons berdasarkan skala Likert 5 poin $(1=$ tidak pernah, 2 = jarang, 3 = kadang-kadang, $4=$ sering, dan 4 = selalu). Skala ini memiliki koefisien reliabilitas $\alpha=0,922$.

\section{Desain penelitian}

Penelitian ini merupakan penelitian eksperimen kuasi atau semu (quasi experimental research) yaitu eksperimen yang dilakukan tanpa randomisasi, namun memiliki tujuan dan atribut struktural yang sama dengan randomized experiments (Shadish, Cook, \& Campbell, 2002). Kuasi eksperimen dilakukan untuk melihat pengaruh pelatihan strategi koping fokus emosi terhadap stres akademik mahasiswa. Desain yang digunakan dalam penelitian ini adalah one group pretest-posttest design.
Perlakuan yang diberikan adalah pelatihan strategi koping fokus emosi. Modul pelatihan menggunakan modul yang sebelumnya telah dikembangkan dalam penelitian Rembulan (2009), yang selanjutnya dimodifikasi dalam hal penyesuaian waktu setiap sesinya. Pemadatan waktu pelatihan didasarkan pada kebutuhan di lapangan terkait adanya kebutuhan treatment yang tidak mengambil banyak waktu bagi mahasiswa. Lebih jauh, pertimbangan lainnya karena modul ini juga telah diujicobakan sebelumnya pada partisipan dengan karakteristik yang relatif sama, yaitu remaja. Peneliti tidak mengubah konten, materi, dan teknis cara penyampaian materi dalam proses pelatihan. Modul ini terdiri dari delapan sesi yang terdiri dari beberapa materi, yaitu: pembukaan, mengenal emosi, mengidentifikasi dan menerima pengalaman emosional, mengekspresikan emosi ke dalam simbol/kata-kata, melihat emosi yang adaptif dan maladaptif, mengidentifikasi pikiran destruktif, memfasilitasi bentuk koping yang lebih adaptif, dan penutup. Penyampaian materi diberikan melalui metode sharing, games, diskusi, penugasan, praktik/latihan langsung, reviu, umpan balik, ceramah dan refleksi. Pelatihan diberikan oleh seorang psikolog yang telah memiliki pengalaman dalam memberikan pelatihan, serta menguasai materi pelatihan strategi koping fokus emosi. Trainer juga akan didampingi oleh co-trainer yang merupakan mahasiswa S-1 Psikologi yang akan membantu jalannya proses pelatihan.

Ethical consideration

Ethical consideration 
Sebelum berpartisipasi dalam penelitian, setiap peserta telah diminta untuk membaca informasi detail terkait penelitian dan memberikan persetujuannya secara sukarela untuk mengikuti penelitian. Ethical clearance atau kelayakan etik telah diterbitkan oleh komisi etik penelitian Fakultas Psikologi Universitas Gadjah Mada dengan nomor 8939/UN1/FPSi.1.3/SD/PT/2019. Setiap informasi yang diberikan peserta akan dijaga kerahasiaannya dengan cara semua nama partisipan akan disamarkan serta semua data yang diperoleh disimpan secara aman.

\section{Analisis data}

Pengujian hipotesis dilakukan dengan menggunakan pendekatan statistik paired sample t-test untuk melihat perbedaan skor pra-perlakuan dan pasca-perlakuan dalam sebuah kelompok. Seluruh perhitungan statistik dalam penelitian ini dilakukan dengan menggunakan program komputer Statistical Package for Social Sciences (SPSS) 17.0. for Windows.

\section{Hasil}

Partisipan dalam penelitian $(n=16)$ berasal dari salah satu Perguruan Tinggi di Yogyakarta, Indonesia, yang terdiri dari beberapa fakultas yang berbeda. Usia partisipan berkisar dari usia 18 hingga 22 tahun $(M=19,81$ tahun; $S D=0,911)$. Sebanyak 2 partisipan adalah laki-laki, dan 14 partisipan adalah perempuan. Ada tiga angkatan yang berbeda, yaitu 11 partisipan merupakan mahasiswa tahun ketiga, 3 partisipan merupakan mahasiswa tahun kedua, dan 2 partisipan merupakan mahasiswa tahun pertama.

Berdasarkan hasil pengukuran, terjadi perubahan skor koping fokus emosi sebelum $(M=52,75 ; S D=4,297)$ dan setelah $(M=56,31 ; S D=4,332)$ diberikannya perlakuan. Perubahan skor juga tampak pada stres akademik dengan ditandai adanya penurunan dari sebelum intervensi $(M=97,50 ; S D=15,548)$ dibandingkan dengan setelah mendapatkan intervensi $(M$ $=91,13 ; S D=21,694)$. Secara lebih jelas dapat dilihat pada Gambar 1 dan Gambar 2.

Sebelum masuk pada analisis lebih jauh, dilakukan uji asumsi normalitas untuk mengetahui apakah skor subjek pada hasil pengukuran memiliki sebaran data yang normal. Uji normalitas dengan menggunakan teknik Kolmogorov - Smirnov (K-S Z) menunjukkan bahwa distribusi data partisipan yang terlibat dalam penelitian ini berdistribusi normal $(p>0,05)$. Langkah selanjutnya adalah melakukan cek manipulasi untuk mengetahui pengaruh perlakuan yang diberikan terhadap koping fokus emosi pada partisipan. Hasil analisis skor koping fokus emosi menggunakan paired sample $t$-test menunjukkan perolehan nilai $t(15)=-2,643 ; p=0,018(p<0,05)$. Hal ini menunjukkan bahwa terdapat perbedaan yang signifikan pada skor koping fokus emosi sebelum dan setelah diberikan pelatihan. 


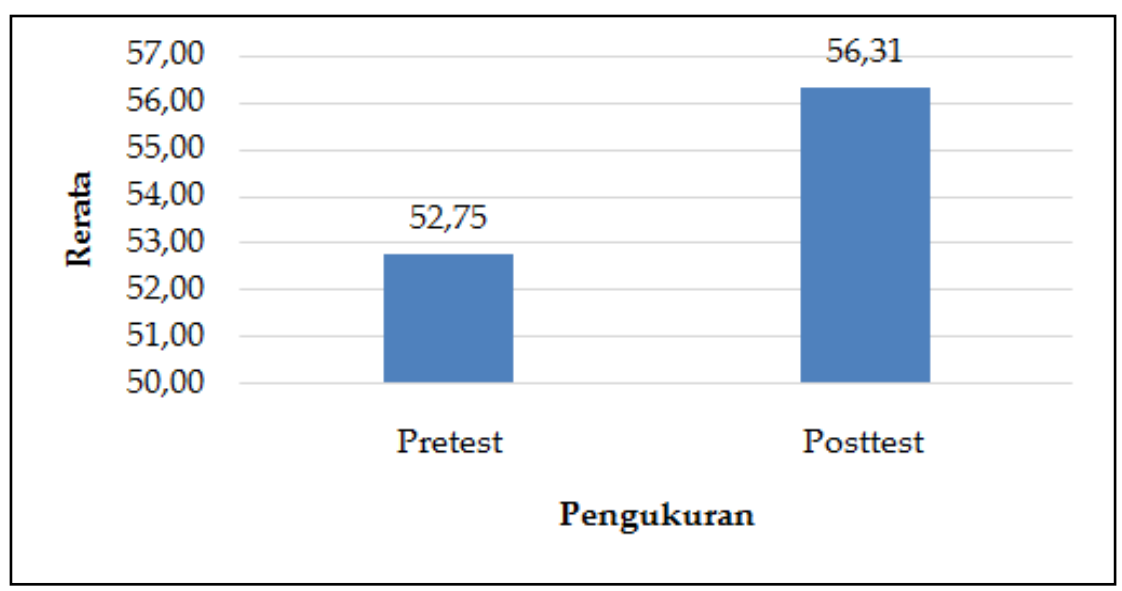

Gambar 1. Perubahan rerata skor koping fokus emosi sebelum dan setelah intervensi

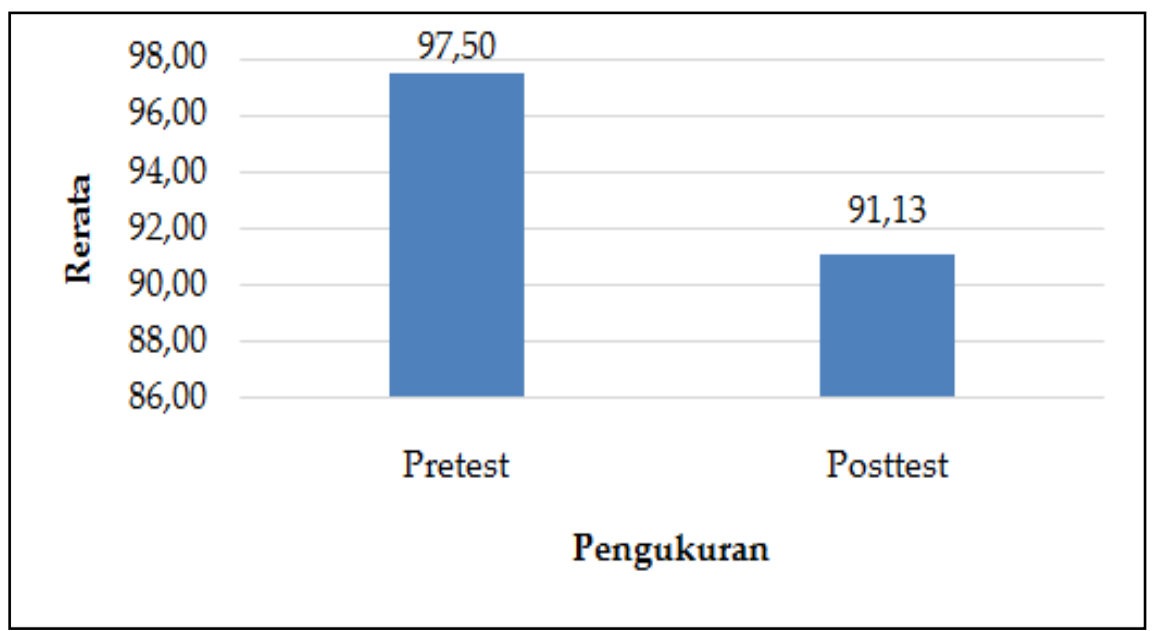

Gambar 2. Perubahan rerata skor stres akademik sebelum dan setelah intervensi

Langkah berikutnya adalah pengujian hipotesis dengan tujuan untuk melihat adanya pengaruh pelatihan strategi koping fokus emosi terhadap stres akademik. Berdasarkan hasil analisis skor stres akademik menggunakan paired sample t-test diperoleh $\mathrm{t}(15)=2,149 ; \mathrm{p}=0,048(\mathrm{p}<0,05)$. Hal ini membuktikan bahwa terdapat perbedaan yang signifikan pada skor stres akademik sebelum dan setelah diberikan pelatihan. Dari analisis tersebut dapat disimpulkan bahwa hipotesis yang menyatakan bahwa pelatihan strategi koping fokus emosi dapat menurunkan stres akademik pada mahasiswa diterima.

\section{Diskusi}

Studi ini menunjukkan bahwa pelatihan strategi koping fokus emosi terbukti dapat menurunkan stres akademik pada mahasiswa. Dinamika yang terjadi ditandai dengan meningkatnya kemampuan mahasiswa untuk melakukan strategi koping yang adaptif, yaitu melalui koping fokus emosi. Strategi koping fokus emosi memberikan ruang bagi mahasiswa untuk dapat mengatur kondisi emosinya melalui berbagai kegiatan ataupun teknik sehingga ia tidak akan terperangkap dalam kungkungan emosi-emosi negatif. Dengan begitu, individu akan lebih mampu 
mengambil langkah-langkah solusi yang adaptif, rasional, dan konkret. Ia juga mampu memandang kondisi secara lebih positif, yang tidak menimbulkan distress. Meningkatnya skor koping fokus emosi pada seluruh partisipan mengindikasikan bahwa pelatihan ini telah memiliki dampak yang nyata. Mahasiswa akan mampu menghadapi berbagai stressor yang dihadapi dalam dunia akademik sehingga meminimalkan terjadinya stres akademik.

Penelitian ini merupakan pengembangan dari penelitian Rembulan (2009) dengan partisipan yang berbeda. Meskipun begitu, hasilnya sejalan dengan studi ini dan semakin menguatkan bahwa modul pelatihan strategi koping fokus emosi terbukti mampu mengatasi permasalahan psikologi yang dihadapi remaja, dalam penelitian ini tingkat stres akademik. Studi korelasional yang dilakukan oleh Refi (2019) juga menunjukkan bahwa semakin tinggi kemampuan koping fokus emosi seseorang maka akan semakin rendah tingkat stres akademik yang dirasakan. Tidak hanya itu, studi lain menunjukkan bahwa koping fokus emosi juga akan mampu meningkatkan kepuasan hidup pada mahasiswa (Sari, 2019).

Dalam "Encyclopedia of Personality and Individual Differences", dijelaskan bahwa strategi koping fokus emosi bisa dibagi menjadi dua sub kategori, yaitu koping berorientasi pada emosi (emotion oriented) dan koping berorientasi pada penghindaran (avoidance). Koping yang berorientasi pada emosi (emotion oriented) ditunjukkan dengan kemampuan individu untuk dapat melakukan pengelolaan emosi, sedangkan koping yang berfokus pada penghindaran (avoidance) dicirikan dengan self-distraction untuk mencoba menghindari stressor yang dianggap maladaptif (Ben-Zur, 2017). Pelatihan yang disasar dalam modul pelatihan ini adalah strategi koping fokus yang berorientasi pada emosi (emotion oriented) yang aktif, di mana psikolog akan mengajarkan mahasiswa dengan berbagai teknik untuk mengelola emosi. Proses dimulai dari kemampuan untuk mengidentifikasi emosi, menerima pengalaman emosional, bagaimana cara mengekspresikannya secara adaptif, kaitannya dengan pikiran, hingga pada berbagai teknik untuk mengelola emosi secara positif.

Dasar pengembangan dari tahapan dalam pelatihan ini mengacu pada konsep Greenberg (2004) dengan membantu individu menjadi sadar, menerima, dan memahami pengalaman emosional mereka. Sebelum sampai pada teknik pengelolaan emosi, individu akan diarahkan untuk dapat betul-betul mampu mengenali emosinya sendiri. Proses dialog dan refleksi dirancang agar peserta dapat lebih aware dengan kondisi emosinya sehingga kemudian mampu mengontrolnya secara adaptif. Individu juga akan menjadi mampu untuk mengungkapkan emosinya secara tepat terutama ketika mereka menghadapi pengalaman yang menegangkan ataupun dalam keadaan sehari-hari secara umum.

Bila dikaitkan dengan konteks mahasiswa, dengan terbekalinya mahasiswa dengan koping fokus emosi yang adaptif, maka setiap stressor akademik yang dihadapi akan mampu dipandang secara lebih positif. Ketika mereka mengalami kendala, ia tidak akan berhenti di sana. Ia dapat meregulasi kondisi 
internal dirinya sehingga terbebas dari kungkungan emosi dan pikiran negatif yang menghambatnya untuk menyelesaikannya. Cara pengatasan fokus emosi tersebut dilakukan dengan tidak hanya melalui regulasi kondisi emosi, melainkan juga secara kognitif, fisiologis, dan perilaku ketika menghadapi tekanan akademik (Ben-Zur, 2017). Dalam studi ini, tampak adanya perubahan skor stres akademik pada semua partisipan. Dari 16 partisipan yang terlibat, terdapat 3 subjek yang mengalami perubahan kategori. Dua di antaranya dari kategori sedang menjadi kategori rendah, dan satu subjek dari kategori tinggi menjadi kategori sedang.

Tugas-tugas, ujian, dan segala kewajiban akademik di kampus ternyata menjadi sumber stres tersendiri bagi para partisipan, terlebih mereka semua berasal dari angkatan yang masih aktif mengambil jadwal perkuliahannya secara penuh setiap semesternya. Beberapa di antaranya merupakan perantau sehingga mereka perlu melakukan penyesuaian diri secara lebih jauh, termasuk penyesuaian sosial budaya. Dinamika stres akademik yang dihadapi dalam partisipan tampak adanya kemiripan dengan studi yang dilakukan di negara lain (Aderi et al., 2013; Beiter et al., 2015; Thurber \& Walton, 2012; Tran et al., 2018). Hal ini seperti yang diungkap oleh Sarros dan Densten (1989), yaitu bahwa pengalaman dan harapan mahasiswa cenderung bersifat umum dialami di berbagai negara atau bisa dikatakan tidak spesifik secara budaya (Sarros \& Densten, 1989).

Folkman dan Lazarus (1985) dalam studinya menambahkan bahwa proses koping merupakan dinamika yang kompleks. Individu sangat mungkin mengombinasikan beberapa bentuk strategi koping dalam mengatasi masalah, sebagai contoh emotion-focused coping dengan problem-focused coping dan bisa juga dengan seeking social support. Berbagai dinamika kombinasi di dalamnya sangat mungkin dilakukan melihat adanya perbedaan individual. Individu satu dengan individu yang lain dapat memiliki opsi atau kombinasinya masing-masing yang dirasa paling efektif bagi dirinya. Terlepas dari itu semua, emotion-focused coping menjadi salah satu langkah awal yang penting untuk dilakukan. Ketika individu masih terkungkung dengan emosi-emosi negatif, sangat mungkin dirinya tidak mampu melihat solusi dan pemecahan masalah ke depan. Juth, Dickerson, Zoccola, dan Lam (2015) mengungkapkan bahwa strategi koping fokus emosi berkaitan erat dengan penilaian kognitif yang lebih positif. Hal ini juga tentunya akan mengarahkan pada afek positif yang lebih dominan, di satu sisi afek negatif yang lebih rendah. Koping yang berfokus pada emosi juga dihubungkan dengan kesehatan fisik dan mental yang lebih positif, salah satunya karena mampu menurunkan tingkat distress yang dialami (Stanton et al., 2000).

Hal yang menjadi tantangan adalah status mahasiswa sarjana yang disandang tidak bisa dilepaskan pula pada tahapan perkembangannya sebagai seorang remaja. Masa remaja kerap digambarkan sebagai masa kekacauan emosional di mana remaja akan mengalami "storm and stress". Kematangan emosi dari para mahasiswa yang merupakan remaja masih perlu untuk menjadi perhatian. Selain masih sulit untuk mengenali emosinya, remaja cenderung 
merasakan emosi yang lebih ekstrem dan emosi yang lebih cepat dibandingkan dengan orang dewasa (Santrock, 2016). Dengan dibekali kemampuan strategi koping fokus emosi yang adaptif, ia dapat lebih aware dengan proses emosi yang terjadi dalam dirinya. Hal ini dimulai dari bagaimana ia menjadi mampu mengidentifikasi perasaan-perasaan yang ia sebenarnya rasakan, dan bukan mengingkarinya ataupun merespons dengan cara yang salah. Setelah mampu memahami kondisi emosi, ia pun menjadi dapat menggunakan pikiran rasionalnya dalam memandang setiap kondisi, bukan terbawa oleh pikiran yang justru destruktif. Ia akan terbiasa untuk dapat mengembangkan pikiran bahwa kondisi sulit yang dihadapi adalah sebuah tantangan, bukan sebagai sebuah ancaman. Sebagai seorang remaja, ia pun juga menjadi memiliki berbagai cara untuk dapat mengontrol kondisi emosi yang menyertai. Dengan begitu, maka yang akan muncul bukanlah perilaku impulsif sebagai luapan dari emosi negatif, melainkan kemampuan untuk mengekspresikan dengan cara yang adaptif dengan disertai pengembangan skema berpikir yang positif. Teknik ini yang dikembangkan dalam studi Greenberg (2004). Dari dinamika inilah tercermin bahwa tingkat stres yang dihadapi mahasiswa menjadi menurun. Sebagaimana yang disampaikan oleh Lazarus dan Folkman (1984) bahwa dengan kemampuan emotion-focused coping yang adaptif, maka respons-respons emosional yang muncul dari kondisi yang menekan dapat diatasi sehingga tidak menjadi sebuah tekanan mental yang dirasakan. Temuan Ender, Parker, dan Butcher (1993) juga menunjukkan bahwa cara koping yang berorientasi pada emosi berkaitan erat dengan tinggi rendahnya distres dan permasalahan psikologi yang dirasakan.

Dari penjelasan tersebut, tampak pelatihan strategi koping fokus emosi menjadi hal penting sebagai upaya untuk membekali remaja dalam menyongsong kehidupan akademiknya di Perguruan Tinggi yang mana memerlukan berbagai bentuk penyesuaian. Program pelatihan ini dapat dikategorikan sebagai upaya preventif penanganan masalah kesehatan mental pada mahasiswa. Sebagaimana telah disebutkan sebelumnya bahwa berbagai studi menunjukkan adanya peningkatan prevalensi stres dan gangguan mental di kalangan pelajar di berbagai negara (Auerbach et al., 2018; Eisenberg et al., 2007). Ketika gangguan mental tersebut tidak segera diatasi, maka dapat berkembang menjadi permasalahan yang lebih serius di masa dewasa (Copeland \& Shanahan, 2009). Hal ini sejalan dengan apa yang disampaikan dan ditekankan oleh World Health Organization (WHO) bahwa upaya preventif merupakan salah satu cara paling efektif untuk mengurangi beban yang dapat muncul dari permasalahan kesehatan mental (World Health Organization, 2004).

Penelitian ini memiliki beberapa kelemahan. Pertama, ukuran sampel yang relatif kecil membuat hasil penelitian ini belum dapat digeneralisasi pada sampel yang lain secara lebih luas. Keterbatasan kedua adalah tidak adanya kelompok kontrol sebagai pembanding dampak perlakuan. Hal ini mengakibatkan ancaman terhadap validitas kesimpulan penelitian karena tidak dapat dipisahkannya efek perlakuan dengan variable extraneous (efek 
hal-hal yang berkorelasi dengan perlakuan) (Shadish et al., 2002). Terlepas dari segala keterbatasan tersebut, penelitian ini dapat memperkuat penelitian sebelumnya yang telah dilakukan bahwa pelatihan strategi koping fokus emosi dapat mengatasi permasalahan psikologis pada remaja, dalam hal ini menurunkan stres akademik yang dialami oleh mahasiswa.

\section{Kesimpulan}

Berdasarkan hasil penelitian dapat disimpulkan bahwa ada penurunan tingkat stres akademik yang signifikan pada mahasiswa setelah mengikuti program pelatihan strategi koping fokus emosi. Hal ini berarti bahwa hipotesis yang diajukan dalam penelitian, yaitu "pelatihan strategi koping fokus emosi dapat menurunkan stres akademik pada mahasiswa" diterima. Setelah mengikuti pelatihan strategi koping fokus emosi, individu belajar mengenai bagaimana cara mengidentifikasi, mengelola, dan mengekspresikan emosinya secara adaptif ketika menghadapi masalah, terutama stressor akademik. Dengan peningkatan kemampuan fokus koping emosi, maka tingkat stres akademik yang dirasakan menjadi menurun sehingga ia menjadi lebih sehat mental. Hasil penelitian ini diharapkan dapat digunakan sebagai salah satu referensi upaya preventif dalam menangani permasalahan psikologis pada mahasiswa, khususnya terkait stres akademik.

Saran

Penelitian selanjutnya diharapkan dapat menggunakan desain eksperimen lain yang menggunakan kelompok kontrol dan dengan jumlah subjek yang lebih besar. Sebagaimana disampaikan sebelumnya yaitu bahwa hal ini menjadi salah satu kelemahan dalam penelitian ini. Dengan penggunaan desain penelitian lain yang disertai kelompok kontrol serta penggunaan subjek yang lebih besar, maka diharapkan dapat semakin membuktikan efektivitas dari modul pelatihan strategi koping fokus emosi dalam penelitian. Selain itu, akan lebih baik pula dalam penelitian selanjutnya dilakukan follow-up test untuk mengetahui apakah efek dari intervensi yang diberikan dapat bertahan dalam jangka waktu yang lama. Peneliti juga berharap bahwa hasil dari penelitian ini dapat mendorong adanya pengembangan studi lebih jauh mengenai intervensi kesehatan mental bagi mahasiswa, terlebih melihat kebutuhan di lapangan yang cukup besar. Melalui berbagai pengembangan studi intervensi bagi mahasiswa diharapkan dapat menurunkan prevalensi permasalahan kesehatan mental yang terjadi di kalangan mahasiswa.

\section{Kepustakaan}

Ababu, G. B., Yigzaw, A. B., Besene, Y. D., \& Alemu, W. G. (2018). Prevalence of adjustment problem and its predictors among first-year undergraduate students in Ethiopian university: A cross-sectional institution based study. Psychiatry Journal, 1-7. doi: $\underline{10.1155 / 2018 / 5919743}$

Aderi, M., Jdaitawi, M., Ishak, N. A., \& Jdaitawi, F. (2013). The influence of demographic variables on university students ' adjustment in North Jordan. International Education Studies, 6(2), 
172-178. doi: 10.5539/ies.v6n2p172

Aini, N. (2017). Identifying the sources of academic stress and coping strategies in new nursing students. In Advances in Health Sciences Research (Vol. 2, pp. 73-81). doi: 10.2991/hsic-17.2017.11

Al-Dubai, S. A. R., Al-Naggar, R. A., Alshagga, M. A., \& Rampal, K. G. (2011). Stress and coping strategies of students in a medical faculty in Malaysia. Malaysian Journal of Medical Sciences, 18(3), 57-64.

Atwater, E. (1983). Psychology of adjustment: Personal growth in a change world (Edisi kedua). New Jersey: Prentice Hall.

Auerbach, R. P., Mortier, P., Bruffaerts, R., Alonso, J., Benjet, C., Cuijpers, P., ... WHO WMH-ICS Collaborators. (2018). WHO world mental health surveys international college student project: Prevalence and distribution of mental disorders. Journal of Abnormal Psychology, 127(7), 623-638. doi: 10.1037/abn0000362

Bamuhair, S. S., Farhan, A. I. Al, Althubaiti, A., Agha, S., Rahman, S. ur, \& Ibrahim, N. O. (2015). Sources of stress and coping strategies among undergraduate medical students enrolled in a problem-based learning curriculum. Journal of Biomedical Education, 1-8. doi: $\underline{10.1155 / 2015 / 575139}$

Beiter, R., Nash, R., McCrady, M., Rhoades, D., Linscomb, M., Clarahan, M., \& Sammut, S. (2015). The prevalence and correlates of depression, anxiety, and stress in a sample of college students. Journal of Affective Disorders, 173, 90-96. doi: $\underline{10.1016 / j . j a d .2014 .10 .054}$
Ben-Zur, H. (2017). Emotion-focused coping. In T. K. S. Virgil Zeigler-Hill (Ed.), Encyclopedia of personality and individual differences. New York: Springer.

Chou, P. C., Chao, Y. M. Y., Yang, H. J., Yeh, G. L., \& Lee, T. S. H. (2011). Relationships between stress, coping and depressive symptoms among overseas university preparatory Chinese students: A cross-sectional study. BMC Public Health, 11(352), 1-7. doi: 10.1186/1471-2458-11-352

Copeland, W. E., \& Shanahan, L. (2009). Which childhood and adolescent psychiatric disorders predict which young adult disorders? Archives of General Psychiatry, 66(7), 764-772. doi: doi:

10.1001/archgenpsychiatry.2009.85

Eisenberg, D., Gollust, S. E., Golberstein, E., \& Hefner, J. L. (2007). Prevalence and correlates of depression, anxiety, and suicidality among university students. American Journal of Orthopsychiatry, 77(4), 534-542. doi: 10.1037/0002$\underline{9432.77 .4 .534}$

Endler, N. S., \& Parker, J. D. A. (1990). Multidimensional assessment of coping: A critical evaluation. Journal of Personality and Social Psychology, 58(5), 844-854. doi: $\quad \underline{10.1037 / 0022-}$ $\underline{3514.58 .5 .844}$

Endler, N. S., \& Parker, J. D. A. (1994). Assessment of multidimensional coping: Task, emotion, and avoidance strategies. Psychological Assessment, $6(1), \quad 50-60$. doi: 10.1037/1040$\underline{3590.6 .1 .50}$

Endler, N. S., Parker, J. D. A., \& Butcher, J. N. (1993). A factor analytic study of 
coping styles and the MMPI-2 content scales. Journal of Clinical Psychology, 49(4), 523-527. doi: 10.1002/10974679(199307)49:4<523::AIDJCLP2270490409>3.0.CO;2-M

Folkman, S., \& Lazaus, R. S. (1985). If it changes it must be a process: Study of emotion and coping during three stages of a collage examination. Personality and Social Psycology, 48(1), 150-170. doi: 10.1037//0022$\underline{3514.48 .1 .150}$

Greenberg, L. S. (2004). Emotion-focused therapy. Clinical Psychology and Psychotherapy, 11, 3-16. doi: 10.1002/cpp.388

Gustems-Carnicer, J., Calderón, C., \& Calderón-Garrido, D. (2019). Stress, coping strategies and academic achievement in teacher education students. European Journal of Teacher Education, 42(3), 375-390. doi: $\underline{10.1080 / 02619768.2019 .1576629}$

Hussain, A., Kumar, A., \& Husain, A. (2008). Academic stress and adjustment among high school students. Journal of the Indian Academy of Applied Psychology, 34, 70-73.

Juth, V., Dickerson, S. S., Zoccola, P. M., \& Lam, S. (2015). Understanding the utility of emotional approach coping: Evidence from a laboratory stressor and daily life. Anxiety Stress Coping, 28(1), 50-70. doi: 10.1080/10615806.2014.921912

Khan, M. J., Altaf, S., \& Kausar, H. (2013). Effect of perceived academic stress on students' performance. FWU Journal of Social Sciences, 7(2), 146-151.

Kumaraswamy, N. (2013). Academic stress, anxiety and depression among college students - A brief review. International Review of Social Sciences and Humanities, 5(1), 135-143.

Lazarus, R. S. (1976). Patterns of adjustment (Edisi ketiga). Tokyo: McGraw-Hill Kogakusha.

Lazarus, R. S., \& Folkman, S. (1984). Stress, appraisal, and coping. New York: Springer.

Maulana, Z. F., Soleha, T. U., Saftarina, F., \& Siagian, J. (2014). Perbedaan tingkat stres antara mahasiswa tahun pertama dan tahun kedua di Fakultas Kedokteran Universitas Lampung. Medical Journal of Lampung University, 3(4), 154-162.

Misra, R., \& McKean, M. (2000). College students' academic stress and its relation to their anxiety, time management, and leisure satisfaction. American Journal of Health Studies, 16(1), 41-51.

Nevid, J. S., Rathus, S. A., \& Greene, B. (2014). Abnormal psychology in a changing world (Edisi kesembilan). Boston: Pearson.

Nugraheni, A. K. (2012). Stres akademik dan kesejahteraan subjektif pada mahasiswa tingkat pertama dan mahasiswa tingkat akhir (Tesis tidak dipublikasikan). Yogyakarta: Fakultas Psikologi Universitas Gadjah Mada.

Park, S. H., \& Kim, Y. (2018). Ways of coping with excessive academic stress among Korean adolescents during leisure time. International Journal of Qualitative Studies on Health and WellBeing, 13(1). doi: $\underline{10.1080 / 17482631.2018 .1505397}$

Pascoe, M. C., Hetrick, S. E., \& Parker, A. G. (2020). The impact of stress on 
students in secondary school and higher education. International Journal of Adolescence and Youth, 25(1), 104112. doi: $\underline{10.1080 / 02673843.2019 .1596823}$

Passer, M. W., \& Smith, R. E. (2007). Psychology: The science of mind and behavior (Edisi ketiga). New York: McGraw-Hill Companies, Inc.

Refi. (2019). Hubungan antara emotion focused coping dan dukungan sosial dengan stres akademik siswa SMA "X" Yogyakarta. In Prosiding Seminar Nasional Magister Psikologi Universitas Ahmad Dahlan (hal. 263-272). Yogyakarta: Universitas Ahmad Dahlan.

Rembulan, C. L. (2009). Penguatan resiliensi dengan pelatihan strategi koping fokus emosi pada remaja putri yang tinggal di panti asuhan (Tesis tidak dipublikasikan). Yogyakarta: Fakultas Psikologi Universitas Gadjah Mada.

Santrock, J. W. (2016). A topical approach to life-span development (Edisi kedelapan). New York: McGraw-Hill.

Sapranaviciute, L., Padaiga, Z., \& Pauzienè, N. (2013). The stress coping strategies and depressive symptoms in international students. Procedia - Social and Behavioral Sciences, 84, 827-831. doi: $\underline{10.1016 / j . s b s p r o .2013 .06 .655}$

Sari, E. N. M. (2019). Hubungan antara emotion focused coping dan kepuasan hidup pada mahasiswa. Cognicia, 7(1), 95-111.

Sarros, J. C., \& Densten, I. L. (1989). Undergraduate student stress and coping strategies. Higher Education Research \& Development, 8(1), 47-57. doi: $\underline{10.1080 / 0729436890080105}$
Shadish, W. R., Cook, T. D., \& Campbell, D. T. (2002). Experimental and quasiexperimental designs for generalized causal inference. Boston: Houghton Mifflin Company.

Shirom, A. (1986). Students' stress. Higher Education, 15, 667-676. doi: $\underline{10.1007 / B F 00141403}$

Stanton, A. L., Danoff-Burg, S., Cameron, C. L., Bishop, M., Collins, C. A., Kirk, S. B., ... Twillman, R. (2000). Emotionally expressive coping predicts psychological and physical adjustment to breast cancer. Journal of Consulting and Clinical Psychology, 68(5), 875-882. doi: 10.1037/0022$\underline{006 X .68 .5 .875}$

Taylor, S. E. (1995). Health psychology (Edisi ketiga). New York: McGraw Hill.

Thurber, C. A., \& Walton, E. A. (2012). Homesickness and adjustment in university students. Journal of American College Health, 60(5), 415-419. doi: $\underline{10.1080 / 07448481.2012 .673520}$

Tran, A. G. T. T., Lam, C. K., \& Legg, E. (2018). Financial stress, social supports, gender, and anxiety during college: A stress-buffering perspective. The Counseling Psychologist, 46(7), 846-869. doi: $\underline{10.1177 / 0011000018806687}$

Wilks, S. E. (2008). Resilience amid academic stress: The moderating impact of social support among social work students. Advances in Social Work, 9(2), 106-125. doi: 10.18060/51

World Health Organization. (2004). Prevention of mental disorders: effective interventions and policy options: summary report / a report of the World Health Organization Dept. of Mental 
Health and Substance Abuse; in collaboration with the Prevention Research Centre of the Universities . World Health Organization. Geneva. Diakses melalui https://apps.who.int/iris/handle/10665 $\not 43027$

Yovita, M., \& Asih, S. R. (2017). The effects of academic stress and optimism on subjective well-being among first-year undergraduates. In A. A. Ariyanto, $\mathrm{H}$. Muluk, P. Newcombe, F. P. Piercy, E. K. Poerwandari, \& S. H. R. Suradijono (Eds.), Diversity in Unity: Perspectives from Psychology and Behavioral Sciences (hal. 559-563). London: Taylor \& Francis Group. 